\title{
STUDY OF PROPOXUR DEGRADING BACTERIA ISOLATED FROM VARIOUS SAMPLING SITE OF RICE FIELD FROM NGAWI
}

\author{
Tirta Kumala Dewi, Hartati Imamuddin, and Sarjiya Antonius \\ Division of Microbiology, Research Center for Biology, Indonesian Institute of Science \\ Jl. Raya Jakarta-Bogor Km.46, Cibinong Science Center,Cibinong \\ e-mail : tirta.kdewi@gmail.com
}

\begin{abstract}
Propoxur (2-isopropoxyphenyl-N-methylcarbamate) is a carbamateinsecticide which has negative impact on the environment. Propoxur is readily degraded by soil microorganism in most soils. Increased enviromental degradation of propoxur constitute the result of increase in activities of soil pesticide-degrading bacteria. The aims of the present study are to isolate andscreen the bacteria with high potential ability to degradepropoxur from soil samples. Isolation and selection were carried out by enrichment cultures technique.Propoxur degrading bacteria were isolated from 5 soil samples in different locations of rice field from Ngawi. The biodegradation ofpropoxur by isolated bacteria were analysed by High Performance Liquid Chromatography (HPLC). Ten consorsia were selected and purified. One isolate was able to use propoxur at $3000 \mathrm{ppm}$ as sole source of carbonfor the growth. The result suggested that $\mathrm{H} 2-\mathrm{NG}$ isolate hydrolysedpropoxur with the yield of 2-isopropoxyphenol and methylamine.
\end{abstract}

Key words: Ngawi, Isolation, Propoxur, Biodegradation, Bacteria

\section{INTRODUCTION}

Propoxur (2-isopropoxyphenil- $N$-methylcarbamate) was a one carbamate pesticides, that was widely used as insecticide in agriculture.Propoxur is one of several pesticides which in some soilsare subject to accelerated or enhanced degradation followingrepeated application. Enhanced degradation of pesticides is presumably the result of anincrease in the numbers or specific activities of soil pesticide-degrading bacteria, but the ecological,physiological, and genetic basis for the adaptation of themicroorganismis not well known (Topp, et.al., 1993).

The enhanced degradation problem and the potentialenvironmental impact of $\mathrm{N}$ methylcarbamate pollution haveprompted studies on the biodegradation of propoxur. A number of propoxur-degrading organisms have been described, including an Arthrobacter sp., (Ouet.al., 1992), a Pseudomonas sp. (Kamanavalli \& Ninnekar, 2000) and a Neisseria subflava (Anusha et.al., 2009). Ouet.al., (1992) and Anusha et.al., (2009) reported the isolation of propoxur-degrading microorganism from various ecosystems. A quick degradation of $\mathrm{N}$-metylcarbamate was showed by Strain ER2 that was isolated from agricultural soil (Topp, et.al., 1993).

A numberof propoxur-degrading pathways have been observed and propoxur metabolism is most often initiated by hydrolysis ofthe labile methylcarbamate linkage, yielding 2isopropoxyphenol and methylamine. Growth generally occurs at the expense of the methylamine, although in some cases the aromatic moiety is metabolized (Topp, et.al.,1993). In this study, we isolated andscreen the bacteria with high potential ability to degrading propoxur from soil samples. 


\section{MATERIALS AND METHODS}

Analytical standards for 2-Isopropoxyphenol was purchased from Sigma Chemical Co.Propoxur Tech was gift from PT IntiEverspring Indonesia. Methylamine was obtained from Merck. All other chemicals were analytical grade and purchased internationally and locally.

Soil samples were collected from five rice field from Ngawi. Soil samples were carefully taken in plastic bag and stored at $4 \stackrel{\circ}{\circ}$. Total of five soil samples from various rice field were collected for the isolation of propoxur-degrading bacteria.

Ten gram of each soil sample was suspended in $90 \mathrm{mLnutrient}$ broth medium in the 250 $\mathrm{mL}$ Erlenmeyer flasks and each was treated with 1000 ppmpropoxur. Erlenmeyer flasks were incubated on a rotary shaker (125 rpm) at room temperature for 10 days.Appropriate dilution was spread onto nutrient agar medium supplemented with propoxur in the same concentration and incubated at room temperature. The appeared bacterial colonies were picked up and purified. Furthermore the bacterial colonies were grown on minimum salt basal (MSB) medium containing 3000 ppm propoxur and tested their ability to degrade propoxur. The concentration of propoxur in the culture supernatant was analyzed by HPLC(SHIMADZU Prominence LC-20A). HPLC chromatograms were produced by injecting $20 \mu \mathrm{L}$ of the supernatant onto a $5 \mu \mathrm{m}$ reverse phase column (LiChrosphere $100 \mathrm{RP}-18$ endcapped) and recorded by ultraviolet detector at $280 \mathrm{~nm}$. The mobile phase was acetonitrile : water $(60: 40(\mathrm{v} / \mathrm{v}))$, flow rate was $1 \mathrm{~mL} / \mathrm{min}$. Theretention time of peaks were compared to those of chemical chompound authentic standards.

\section{RESULTS AND DISCUSSION}

Ten consorsia were selected and purified.Each isolate was grown on MSB medium which propoxur as sole source of carbon for growth. Bacterial strains capable of utilizing propoxur as sole source of carbon were successfully isolated from soil samples by culture enrichment techniques. One isolate designated as $\mathrm{H}-2-\mathrm{NG}$ isolate from soil sample no.2 (Tawun village-Ngasreman, Ngawi) was capable of utilizing propoxurat 3000 ppm as sole source of carbon as single culture. The growth of the $\mathrm{H}-2-\mathrm{NG}$ isolate and its ability to degrade propoxurwas shown in Figure 1. At the beginning incubation (0-24 h), the growth of $\mathrm{H}-2-\mathrm{NG}$ isolate at a concentration of 3000 ppm propoxur in MSB medium as sole source was slowly with the optical density 0,15 , however after 96 hours the optical density was 3,81. It indicated on the lag period, $\mathrm{H}-2-\mathrm{NG}$ isolate adapted to the new environment of medium in addition of propoxur. The lag phase of the isolate depending on the length of the time for which the cells were grown in synthetic medium (Anusha, 2009). The H-2-NGisolate show very rapid growth in the exponential phase. This event indicated thatH-2-NG isolatesynthesizedpropoxur hydrolase enzyme and hydrolysedpropoxur with the yield of 2-isopropoxyphenol and methylamine. It is suggested from this observation that the organisms require some time to get adapted to the xenobiotic metabolism as well as the metabolites.

In fact the H-2-NG isolate was able to utilize 2-isopropoxyphenol when grown on synthetic medium containing 3000 ppm propoxur. This result indicated that $\mathrm{H}-2-\mathrm{NG}$ isolateutilized intermediate compound of propoxur as sole source of carbon by synthesized propoxur hydrolase. H-2-NG isolate were adapted on medium containing propoxur by arranged new 
matter, synthesized new metabolisms pathway to degrade and utilized propoxur as sole source of carbon (Top \& Springael 2003; Springael \& Topp 2004). In the stationary phase occurs depleted nutrient content, resulting in nutrient competition so that some cells die and others continue to grow. The number of cells remains constant.

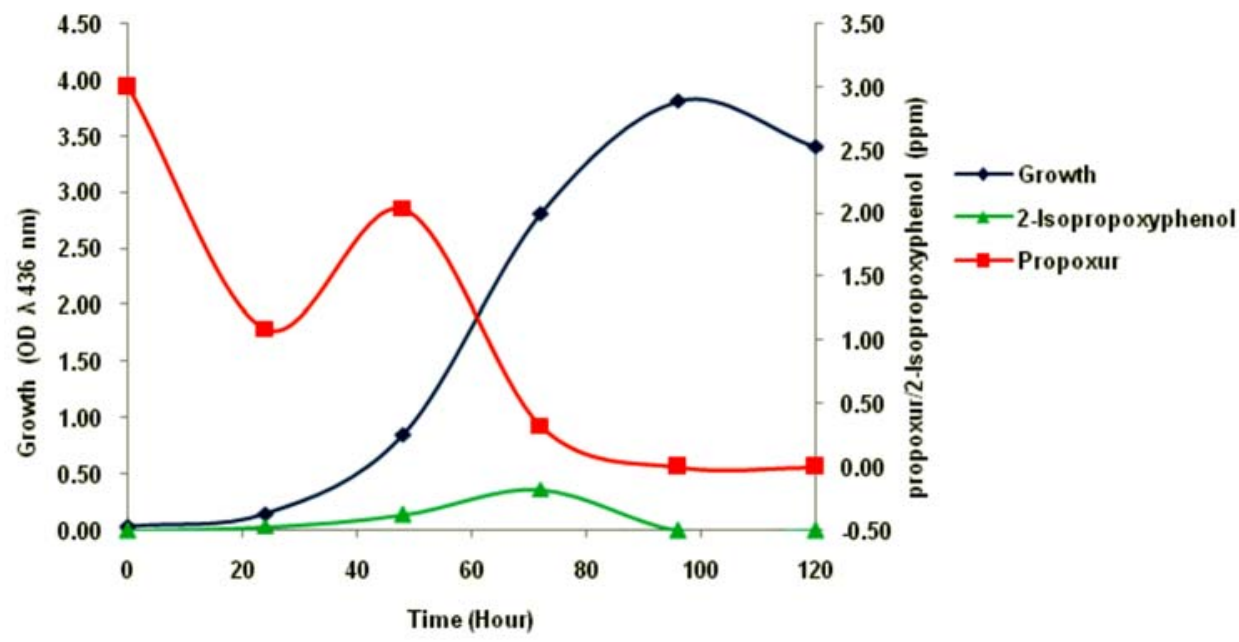

Figure 1. Utilization of propoxur initially $3000 \mathrm{ppm}$ during growthof $\mathrm{H}-2-\mathrm{NG}$ isolate. Propoxur and 2-isopropoxyphenol concentrations were determined by HPLC

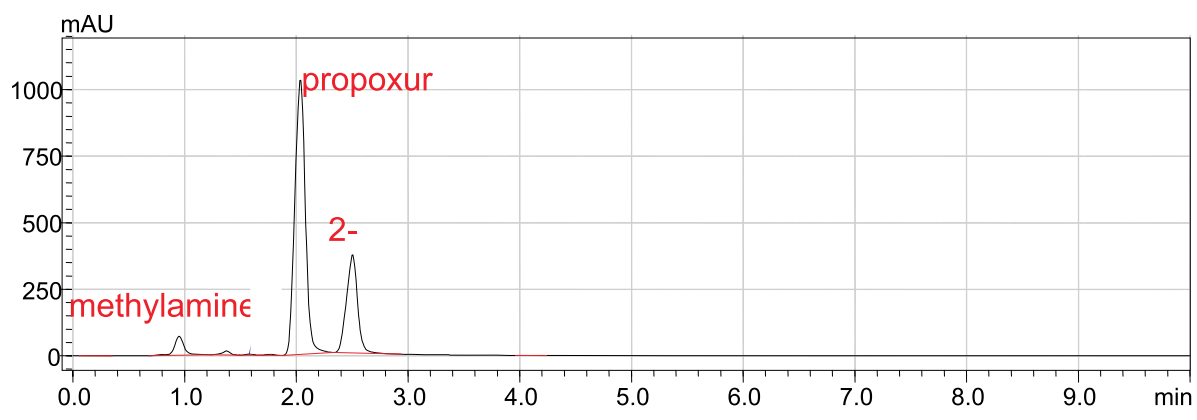

Figure 2. HPLC chromatogram of propoxur at $3000 \mathrm{ppm}$

The concentration of propoxur in culture broth was analysed by High Performance Liquid Chromatography (HPLC). Organismsdegrade propoxur with the yield 2-isopropoxyphenol and methylamine, utilize 2-isopropoxyphenol for growth. Propoxur peak was observed after retention time 2,0 minute, 2-isopropoxyphenol was observed after 2,5 minute and methylamine observed after 0,9 minute. HPLC chromatograms of propoxur-degrading bacteria are shown in Figure 2. H-2-NG isolate degrade propoxur at 3000 ppm during 120 hours. The control that was absent of $\mathrm{H}-2-\mathrm{NG}$ isolate, the concentration of propoxur was remain stable (data not shown).

Kamanavalli and Ninnekar (2000) found that Pseudomonas species has ability to degrade propoxur at $2000 \mathrm{ppm}$, but in this study H-2-NG isolate could degrade propoxur at $3000 \mathrm{ppm}$. Therefore, this isolate has a potencyfor bioremediation and elimination of contaminants in a cheap and environmentally friendly manner. 


\section{ACKNOWLEDGMENT}

This research was funded by DIPA PN Biofertilizer project 2010-2014, Research Center for Biology, Indonesian Institute of Science.

\section{REFERENCES}

Anusha, J., P.K. Kavitha, C.G. Louella, D.M. Chetan, and C.V. Rao. 2009. A study on biodegradation of propoxur by bacteria isolated from municipal solid waste. International Journal of Biotechnology Applications1(2): 26-31

Kamanavalli, C.M., and H.Z. Ninnekar. 2000. Biodegradation of propoxur by Pseudomonas species. World Journal of Microbiology \& Biotechnology 16: 329-331

Ou, L.T., P. Nkedi Kizza, J.L. Cisar, and G.H. Snyder. 1992. Microbial degradation of propoxur in turfgrass soil. Journal of Environmental Science and Health, Part B 27(5): 545-564

Springael, D., and E.M. Topp. 2004. Horizontal gene transfer and microbial adaptation to xenobiotics: new types of mobile genetic elements and lessons from ecological studies. Trends in Microbiology 12(2): 53-58

Topp, E., R.S. Hanson, D.B. Ringelberg, D.C. White, and R. Wheatcroft. 1993. Isolation and characterization of an $\mathrm{N}$-methylcarbamate insecticide-degrading methylotrophic bacterium. Applied and Environmental Microbiology 59(10): 3339-3349

Top, E.M., and D. Springael. 2003. The role of mobile genetic elements in bacterial adaptation to xenobiotic organic compounds. Current Oppinion in Biotechnology 14(3): 262-269 